\title{
ANALISIS RENTABILITAS PADA INDUSTRI PERHOTELAN YANG TERDAFTAR DI BURSA EFEK INDONESIA
}

\author{
Vidya Akandji ${ }^{1}$, Jantje J. Tinangon ${ }^{2}$, Winston Pontoh ${ }^{3}$ \\ ${ }^{1,2,3}$ Jurusan Akuntansi, Fakultas Ekonomi dan Bisnis, Universitas Sam Ratulangi, Jl. Kampus Bahu, Manado, \\ 95115, Indonesia \\ E-mail: vidya.akandji@gmail.com
}

\begin{abstract}
As business increasingly global, financial statements are more important than ever before. As a basis of competitive analysis, credit decisions, business negotiation and legal entity control. For investor or potential investor, it would be better to analyse the company's financial performace first. In assessing the company's financial performance, one of the indicators that mostly used is accounting investment in the form of a company's financial satatement. This study was conducted in the hospitality industry listed on the stock exchange with aim to analyse financial statement in assessing the company's financial performance. The analytical method used in this study is a quantitative analysis method. From the financial statement there is an analysis of profitability to be able to predict the condition of the company's in the future. The results of profitability ratio which consist of profit margin, gross profit margin, net profit margin, ROI, and ROA show that ability of the company to get profits from all sources have varies performances. There are companies which have good, standard and poor performances.
\end{abstract}

Keywords: rentability rasio; financial ratio; Indonesia Stock Exchange

\section{PENDAHULUAN}

Analisis keuangan bertujuan melihat prospek dan risiko perusahaan. Prospek bisa dilihat dari tingkat keuntungan (rentabilitas) dan risiko dapat dilihat dari kemungkinan perusahaan mengalami kesulitan keuangan atau mengalami kebangkrutan. Salah satu indikator yang digunakan untuk mengetahui kondisi keuangan, misalnya tingkat kesehatan suatu perusahaan adalah laporan keuangan.

Laporan keuangan yang disusun pada setiap akhir periode yang berisi pertanggungjawaban keuangan atas berjalannya suatu usaha. Analisis rasio dapat memberikan penilaian terhadap kinerja keuangan perusahaan selain itu juga menjadi pertimbangan bagi investor atau calon investor. Perusahaan yang dimaksud adalah industri perhotelan yang terdaftar di Bursa Efek Indonesia dimana rasio rentabilitas merupakan salah satu faktor yang digunakan sebagai penilaian salah satu kinerja keuangan.

\section{TINJAUAN PUSTAKA}

Akuntansi. Akuntansi adalah seperangkat pengetahuan yang mempelajari perekayasaan dalam penyediaan jasa, yang berupa informasi keuangan dari suatu unit organisasi dan cara penyampaian (pelaporan) informasi tersebut kepada pihak yang berkepentingan untuk dijadikan dasar pengambilan keputusan ekonomi (Pura, 2013:4). Menurut Sucipto (2014:1), akuntansi (accounting) adalah proses tiga aktivitas: identifikasi, pencatatan, dan komunikasi (identifying, recording, and communicating) peristiwa ekonomi sebuah organisasi (bisnis dan non bisnis) bagi pengguna informasi.

Analisis laporan keuangan. Analisis laporan keuangan adalah sebuah penyajian laporan yang terstruktur untuk menjelaskan kondisi keuangan dalam periode tertentu yang terdiri dari neraca, laporan laba rugi, dan laporan perubahan ekuitas. Menurut Kasmir 
(2018:7), laporan keuangan adalah laporan yang menunjukkan kondisi keungan perusahaan saat ini atau periode kedepan. Maksud dan tujuan laporan keuangan menunjukkan kondisi keuangan perusahaan.

Analisis laporan keuangan dapat memberikan gambaran perubahan atas kondisi keuangan atau kinerja operasional selama periode tertentu. Laporan keuangan memberikan informasi tren dan pola perubahan, yang pada akhirnya bisa memberikan indikasi adanya risiko dan peluang bisnis (Kuncoro dan Suhardjono, 2002:557). Beberapa contoh dari tujuan analisis menurut Hanafi dan Halim (2016), yaitu:

1. Investasi pada saham. Investor atau calon investor akan tertarik pada perusahaan dengan tingkat keuntungan yang tinggi dengan risiko yang rendah. Risiko yang berhubungan dengan investasi saham pada dasarnya sama dengan risiko yang berkaitan dengan perusahaan pada umumnya. Analisis risiko bisa difokuskan pada kemampuan perusahaan melewati masa-masa sulit dan kemudian memproyeksikan kemampuan tersebut untuk masa mendatang.

2. Pemberian kredit. Tujuan pokok dari analisis ini yaitu bagaimana melihat kemampuan perusahaan dalam mengembalikan pokok hutang beserta dengan bunganya. Pinjaman ada yang disebut dengan pinjaman jangka panjang dan juga jangka pendek, dan untuk kedua pinjaman ini memiliki fokus analisa yang berbeda-beda.

3. Kesehatan perusahaan ditinjau dari karyawan. Karyawan atau calon karyawan bisa saja akan tertarik menganalisis keuangan perusahaan untuk memastikan apakah perusahaan yang mempekerjakannya memiliki prospek keuangan yang baik. Beberapa hal yang bisa dianalisis antara lain probabilitas keuangan, kondisi keuangan sekarang, dan kemampuan menghasilkan kas.

4. Pemerintah. Pemerintah bisa menganalisis keuangan peusahaan untuk menentukan besar pajak yang akan dibayar perusahaan atau menentukan tingkat keuntungan yang wajar untuk suatu industri. Jika perusahaan akan menjual sahamnya ke pasar modal, maka pemerintah (dalam hal ini BAPEPAM) akan menganalisa keuangan perusahaan untuk menentukan layak tidaknya perusahaan tersebut untuk go public.

5. Analisis internal. Pihak manajemen perusahaan membutuhkan informasi ini untuk melihat sejauh mana perkembangan perusahaan dan bisa juga menjadi bahan evaluasi bagi perusahaan kedepannya.

6. Analisis pesaing. Analisis ini dibutuhkan oleh perusahaan sebagai strategi dalam menentukan harga, strategi merebut pangsa pasar atau keputusan-keputusan lainnya.

7. Penilaian kerusakan. Analisis ini dapat dipakai untuk menentukan kerusakan dan kekuatan perusahaan sehingga bisa menjadi pertimbangan dalam mengambil keputusan selanjutnya.

Analisis rasio keuangan. Analisis rasio keuangan adalah membandingkan angkaangka yang ada dalam laporan keuangan untuk mengetahui posisi keuangan suatu perusahaan serta menilai kinerja manajemen dalam suatu periode tertentu. Analisis rasio keuangan adalah future oriented atau berorientasi pada masa depan, artinya bahwa analisa rasio keuangan dapat digunakan sebagai alat untuk meramalkan keadaan keuangan serta hasil usaha dimasa mendatang (Munawir, 2010:106). Rasio keuangan merupakan alat yang dinyatakan dalam arti relatif maupun absolut yang menjelaskan hubungan tertentu antara angka yang satu dengan angka yang lainnya dalam laporan keuangan (Alwi, 1993:107). Menurut Rahardjo (2009:104), rasio keuangan perusahaan diklasifikasikan menjadi 5 (lima) kelompok yaitu:

a. Rasio likuiditas (liquidity ratios) yaitu jenis rasio yang menunjukkan kemampuan perusahaan untuk memenuhi kewajiban jangka pendek.

b. Rasio solvabilitas (leverage atau solvency ratios) yaitu jenis rasio yang menunjukkan kemampuan perusahaan untuk memenuhi seluruh kewajibannya baik jangka pendek ataupun jangka panjang. 
c. Rasio aktivitas (activity ratios) yaitu jenis rasio yang menunjukkan tingkat efektifitas penggunaan aktiva atau kekayaan perusahaan.

d. Rasio profitabilitas dan atau rentabilitas (profitability ratios) yaitu jenis rasio yang menunjukkan tingkat imbalan atau perolehan keuntungan dibanding penjualan atau aktiva.

e. Rasio investasi (investment ratios) yaitu jenis rasio yang menunjukkan rasio investasi dalam surat berharga atau efek, khususnya saham dan obligasi.

Analisis rentabilitas. Analisis rentabilitas adalah rasio yang digunakan untuk mengukur kemampuan suatu perusahaan untuk mendapatkan laba. Menurut Prihadi (2014) beberapa ukuran rasio rentabilitas yang digunakan antara lain:

1. Net Profit Margin atau Margin Laba Bersih ini digunakan untuk mengukur laba bersih yang dihasilkan oleh setiap penjualan dan mengukur seluruh efisien, baik produksi, administrasi, pemasaran, pendanaan, penentuan harga ataupun manajemen pajak. Semakin tinggi rasio ini menunjukkan kemampuan perusahaan dalam menghasilkan laba yang tinggi pada tingkat penjualan tertentu. Rasio yang rendah menunjukkan penjualan yang terlalu rendah untuk tingkat biaya tertentu, atau biaya yang terlalu tinggi untuk tingkat penjualan tertentu, atau kombinasi dari kedua hal tersebut. Rumus Net Profit Margin adalah:

(Laba bersih $\div$ Penjualan) $\times 100 \%$

Rasio ini mengukur jumlah laba bersih yang diperoleh setiap penjualan. Semakin tinggi rasio Net Profit Margin maka semakin baik kemampuan perusahaan dalam menghasilkan laba yang tinggi pada tingkat penjualan tertentu.

2. Gross Profit Margin adalah perbandingan antara laba kotor yang didapatkan perusahaan dengan tingkat penjualan yang dicapai dalam periode yang sama. Rasio ini menggambarkan laba kotor yang dapat dicapai setiap penjualan. Semakin besar rasio Gross Profit Margin maka semakin baik kondisi keuangan perusahaan. Rumus Gross Profit Margin adalah:

(Laba kotor $\div$ Penjualan bersih) $\times 100 \%$

Rasio ini menunjukkan kemampuan perusahaan dalam menghasilkan laba yang akan menutupi biaya tetap atau biaya operasi lainnya, dimana semakin besar rasionya maka semakin baik.

3. Return on Investment (ROI) adalah kemampuan perusahaan untuk menghasilkan keuntungan yang akan digunakan untuk menutup investasi yang dikeluarkan. Laba yang digunakan untuk mengukur rasio ini yaitu laba bersih setelah pajak atau earnings after tax (EAT). Rumus ROI adalah:

$($ EAT $\div$ Investasi $) \times 100 \%$

Rasio ini mengukur perbandingan laba bersih setelah pajak yang dihasilkan setiap nilai investasi yang dikeluarkan, dimana semakin besar rasio Return on Investment maka semakin baik.

4. Return on Asset (ROA) adalah kemampuan perusahaan dalam menghasilkan laba dengan semua aktiva yang dimiliki perusahaan. Rasio ini disebut juga dengan rentabilitas ekonomis. Laba yang dihasilkan adalah laba sebelum bunga dan pajak atau EBIT. Rumus ROA adalah:

(EBIT $\div$ Total aktiva) $\times 100 \%$

Rasio ini mengukur tingkat keuntungan atau EBIT dari aktiva yang digunakan, dimana semakin besar rasio Return on Asset maka semakin baik.

Penelitian terdahulu. Hasil penelitian Prabowo (2018) menunjukkan bahwa rentabilitas PT. Gudang Garam, Tbk masih mengalami fluktuatif. Ihsan et al. (2017) menunjukkan bahwa kinerja keuangan Bank BNI jika ditinjau melalui rasio rentabilitas pada Bank BNI tahun 2013-2015 dapat dikatakan baik karena rata-rata Return on Assets pada 
Bank BNI adalah 3,2\%, dimana menurut kriteria Bank Indonesia adalah baik karena $>1,22 \%$. Setiawan (2019) menunjukkan bahwa kinerja keuangan PT. Bank SUMUT Kantor Cabang Iskandar Muda masih memiliki rasio rentabilitas yang baik. Mailakay et al. (2017) menunjukkan bahwa terdapat perbedaan yang signifikan pada kinerja keuangan yang diukur dengan analisis rasio rentabilitas menggunakan net profit margin, return on asset, return on equity dan return on investment pada perusahaan telekomunikasi yang ada di Indonesia, dalam hal ini pada PT. Telekomunikasi Indonesia, Tbk dan PT. XL Axiata, Tbk. Mende et al. (2017) menunjukkan bahwa kondisi rasio keuangan yang diukur dengan CR, DER, dan ROA pada perusahaan properti dan real estate selama periode 2012-2015 menunjukkan kondisi yang kurang baik secara umum. Rundupadang et al. (2018) menunjukkan bahwa Capital Adequacy Ratio berpengaruh tidak signifikan terhadap Return on Asset, Non Performing Loan berpengaruh signifikan terhadap Return on Asset, beban operasional dan pendapatan operasional berpengaruh signifikan terhadap Return on Asset, Loan to Deposit Ratio berpengaruh tidak signifikan terhadap Return on Asset.

\section{METODE PENELITIAN}

Jenis penelitian ini adalah studi kasus yaitu, penelitian yang dilakukan terhadap suatu perusahaan. Objek penelitian ini adalah Bursa Efek Indonesia. Metode yang digunakan untuk menganalisis data dalam penelitian ini adalah metode kuantitatif yaitu dengan cara menggambarkan data yang telah terkumpul sebagaimana adanya (Sugiyono, 2010:13). Penelitian ini menggunakan sumber data sekunder berupa laporan keuangan pada industri perhotelan yang terdaftar di Bursa Efek Indonesia tahun 2018. Metode pengumpulan data dalam penelitian ini menggunakan teknik dokumentasi, yang didapat dari pengumpulan data dan informasi melalui buku-buku, jurnal, internet dengan melakukan penelitian terhadap catatan atau dokumen yang ada seperti sejarah perusahaan dan laporan yang disajikan oleh industri perhotelan yang terdaftar di Bursa Efek Indonesia. Adapun langkah-langkah dalam proses analisis data adalah sebagai berikut: (a) mengidentifikasi penyajian neraca, laporan operasional, laporan arus kas, dan catatan atas laporan keuangan; (b) mengidentifikasi pencatatan aset, utang, dan modal pada neraca; (c) mengidentifikasi pencatatan pendapatan dan beban pada laporan operasional; dan (d) membandingkan rasio rentabilitas industri perhotelan yang terdaftar di Bursa Efek Indonesia.

\section{HASIL PENELITIAN DAN PEMBAHASAN \\ 4.1. Hasil penelitian}

Sampel terdiri dari 8 (delapan) perusahaan yang diambil secara acak. Perusahaanperusahaan tersebut adalah sebagai berikut: Island Concepts Indonesia Tbk, PT. Uluwatu Villa Tbk, Hotel Sahid Jaya Tbk, PT. Ayana Land Internasional Tbk, Jakarta International Hotel Tbk, Saraswati Griya Lestari Tbk, Indonesia Paradise Property Tbk dan Hotel Mandarine Regency Tbk. Tabel 1 menyajikan data-data atas sampel yang akan digunakan dalam penelitian ini. 
Tabel 1. Data keuangan sampel (disajikan dalam Rp.)

\begin{tabular}{l} 
Nama Perusahaan \\
\hline Hotel Sahid Jaya Tbk. \\
PT. Ayana Land Internasional Tbk. \\
Jakarta Internasional Hotels dan Development Tbk. \\
Saraswati Griya Lestari Tbk. \\
Indonesia Paradise Property Tbk. \\
PT. Bukit Uluwatu Villa Tbk. \\
Hotel Mandarine Regency Tbk. \\
Island Concepts Indonesia Tbk. \\
\\
Hotel Sahid Jaya Tbk. \\
PT. Ayana Land Internasional Tbk. \\
Jakarta Internasional Hotels dan Developmnet Tbk. \\
Saraswati Griya Lestari Tbk. \\
Indonesia Paradise Property Tbk. \\
PT. Bukit Uluwatu Villa Tbk. \\
Hotel Mandarine Regency Tbk. \\
Island Concepts Indonesia Tbk.
\end{tabular}

Hotel Sahid Jaya Tbk.

PT. Ayana Land Internasional Tbk.

Jakarta Internasional Hotels dan Development Tbk.

Saraswati Griya Lestari Tbk.

Indonesia Paradise Property Tbk.

PT. Bukit Uluwatu Villa Tbk.

Hotel Mandarine Regency Tbk.

Island Concepts Indonesia Tbk.

\begin{tabular}{rr}
\hline \multicolumn{1}{c}{ Laba Kotor } & Penjualan Bersih \\
\hline 147.747 .411 .478 & 189.817 .862 .304 \\
12.490 .380 .319 & 16.297 .795 .249 \\
1.068 .643 .406 & 1.457 .372 .082 \\
69.572 .903 .468 & 124.080 .164 .208 \\
494.429 .858 .772 & 770.398 .351 .932 \\
295.124 .701 .984 & 488.803 .600 .222 \\
-2.333 .113 .044 & 39.067 .266 .092 \\
2.359 .466 .628 & 198.362 .254 .905
\end{tabular}

\begin{tabular}{rr}
\hline \multicolumn{1}{c}{$\begin{array}{c}\text { Laba Bersih } \\
\text { (EAT) }\end{array}$} & \multicolumn{1}{c}{ Investasi } \\
\hline 1.716 .844 .066 & 559.663 .084 .000 \\
257.706 .783 & 1.100 .100 .000 .000 \\
158.378 .702 & 1.164 .520 .241 \\
-11.154 .831 .904 & 355.000 .145 .200 \\
122.894 .269 .254 & 1.118 .197 .173 .200 \\
13.854 .741 .330 & 340.563 .460 .000 \\
-26.173 .578 .401 & 226.655 .048 .800 \\
30.836 .082 .689 & 61.162 .218 .750 \\
& \\
\hline Laba Sebelum & Total Aktiva \\
Bunga & \\
dan Pajak (EBIT) & \\
\hline 2.114 .847 .568 & 1.503 .098 .900 .111 \\
257.706 .783 & 1.168 .208 .737 .518 \\
196.248 .605 & 6.606 .689 .033 \\
-11.735 .188 .628 & 1.205 .126 .235 .213 \\
129.860 .412 .347 & 6.964 .734 .840 .779 \\
22.016 .316 .254 & 4.106 .726 .921 .085 \\
24.418 .529 .471 & 281.193 .747 .615 \\
35.426 .069 .491 & 395.969 .370 .635 \\
\hline
\end{tabular}

Hotel Sahid Jaya Tbk.

PT. Ayana Land Internasional Tbk.

Jakarta Internasional Hotels dan Development Tbk.

Saraswati Griya Lestari Tbk.

Laba Bersih

1.716.844.066

257.706 .783

158.378 .702

$-11.154 .831 .904$

122.894.269.254

13.854 .741 .330

$-26.173 .578 .401$

30.836 .082 .689
Penjualan

189.817.862.304

16.297.795.249

1.457.372.082

124.080.164.208

770.398 .351 .932

488.803.600.222

39.067.266.092

198.362.254.905

Indonesia Paradise Property Tbk.

PT. Bukit Uluwatu Villa Tbk.

Hotel Mandarine Regency Tbk.

Island Concepts Indonesia Tbk.

Sumber data: idx.go.id, 2019

\subsection{Pembahasan}

Berdasarkan Tabel 1, maka Tabel 2 menyajikan hasil perhitungan rentabilitas atas perusahaan-perusahaan yang menjadi sampel penelitian ini.

1. Net Profit Margin (NPM). Tabel 2 menunjukkan bahwa perusahaan Indonesia Paradise Property Tbk, mampu menghasilkan laba tinggi yang mencapai $15,95 \%$, selanjutnya 
Island Concepts Indonesia Tbk menghasilkan 15,55\% dan seterusnya. Sementara Hotel Mandarine Regency Tbk sekalipun dengan Investasi yang lebih ternyata tetap mengalami kerugian sebesar $67 \%$ atas penjualan.

2. Gross Profit Margin (GPM). Tabel 3 menunjukkan bahwa perusahaan Hotel Sahid Jaya Tbk lebih unggul dari perusahaan yang lainnya dalam kemampuan menghasilkan laba yang akan menutupi biaya tetap atau biaya operasi lainnya dan disusul oleh perusahaan PT. Ayana Land Internasional Tbk, Jakarta Internasional Hotels dan Development Tbk dan seterusnya sesuai urutan presentasinya. Perusahaan Hotel Mandarine Regency Tbk. menempati posisi terbawah yang menjelaskan perusahaan tersebut tidak mampu menghasilkan laba yang akan menutupi biaya tetap atau biaya operasi lainnya dalam perusahaan tersebut.

3. Return on Investment (ROI). Tabel 2 menunjukkan bahwa perusahaan Island Concepts Indonesia Tbk menjadi perusahaan dengan presentasi tertinggi yang menghasilkan laba bersih setelah pajak 50,42\% atas investasi yang dikeluarkan, sedangkan Hotel Mandarine Regency Tbk tidak mampu menghasilkan keuntungan (rugi) sebesar 11,55\% atas investasi yang di keluarkan oleh perusahaan.

4. Return on Assets (ROA). Tabel 2 menunjukkan bahwa perusahaan Island Concepts Indonesia Tbk menjadi perusahaan dengan presentasi tertinggi yang menghasilkan laba sebesar $8,95 \%$ dari seluruh aktiva yang dimiliki, sedangkan Saraswati Griya Lestari Tbk memiliki presentasi yang sangat rendah, dan menunjukkan bahwa total aktiva perusahaan tersebut tidak mampu menghasilkan laba.

Tabel 2. Analisis rentabilitas

\begin{tabular}{lrrrr}
\hline \multicolumn{1}{c}{ Nama perusahaan } & NPM & GPM & \multicolumn{1}{c}{ ROI } & ROA \\
\hline Hotel Sahid Jaya Tbk. & $0,90 \%$ & $77,84 \%$ & $0.31 \%$ & $0,14 \%$ \\
PT. Ayana Land Internasional Tbk. & $1,58 \%$ & $76,64 \%$ & $0,02 \%$ & $0,02 \%$ \\
Jakarta Internasional Hotels dan development Tbk. & $10,87 \%$ & $73,33 \%$ & $13,60 \%$ & $2,97 \%$ \\
Saraswati Griya Lestari Tbk. & $-8,99 \%$ & $56,07 \%$ & $-3,14 \%$ & $-0,97 \%$ \\
Indonesia Paradise Property Tbk. & $15,95 \%$ & $64,18 \%$ & $10,99 \%$ & $1,86 \%$ \\
PT. Bukit Uluwatu Villa Tbk. & $2,83 \%$ & $60,38 \%$ & $4,07 \%$ & $0,54 \%$ \\
Hotel Mandarine Regency Tbk. & $-67,00 \%$ & $-5,97 \%$ & $-11,55 \%$ & $8,68 \%$ \\
Island Concepts Indonesia Tbk. & $15,55 \%$ & $1,189 \%$ & $50,42 \%$ & $8,95 \%$ \\
\hline
\end{tabular}

Sumber data: Data olahan, 2019

\section{KESIMPULAN DAN SARAN}

\subsection{Kesimpulan}

Hasil penelitian ini menunjukkan rentabilitas yang merupakan ukuran tingkat keuntungan dari delapan perusahaan yang diteliti memiliki tingkat keuntungan yang beragam. Jakarta Internasional Hotels dan Development Tbk, Indonesia Paradise Property Tbk, dan Island Concepts Indonesia Tbk menunjukkan tingkat keuntungan yang di atas standar industri sedangkan yang menunjukan tingkat keuntungan yang sesuai standar industri yaitu PT. Ayana Land Internasional Tbk, dan PT. Bukit Uluwatu Villa Tbk dan perusahaan yang menunjukan tingkat keuntungan di bawah standar industri adalah Hotel Mandarine Regency Tbk, Hotel Sahid Jaya Tbk, dan Saraswati Griya Lestari Tbk.

\subsection{Saran}

Saran atas penelitian ini agar perusahaan yang memiliki kinerja minimal dapat meningkatkan pendapatan dari penjualan agar bisa menstabilkan GPM, NPM, ROA dan ROI. 


\section{DAFTAR PUSTAKA}

Alwi, S. (1993). Alat-alat analisis dalam pembelajaran, Edisi 3. Yogyakarta: Andi Offset

Hanafi, M. M., \& Halim A. (2016). Analisis laporan keuangan, Edisi 5. Yogyakarta: Unit Pelaksana Proyek Sekolah Tinggi Ilmu Manajemen Yayasan Keluarga Pahlawan Negara.

https://www.idx.co.id/perusahaan-tercatat/laporan-keuangan-dan-tahunan/

https://www.idx.co.id/tentang-bei/sejarah-dan-milestone/

Ihsan, I. N., Ulfah, Y., \& Azis, M. (2017). Analisis perbandingan kinerja keuangan bank melalui pendekatan likuiditas, solvabilitas, dan rentabilitas. Jurnal Manajemen, 9(1), 24-30.

http://journal.feb.unmul.ac.id/index.php/JURNALMANAJEMEN/article/view/2430

Indonesia Capital Market Directory. (2018). Manado: PT. Bursa Efek Indonesia.

Kasmir. (2018). Analisis laporan keuangan. Edisi Revisi. Yogyakarta: Raja Wali Pers.

Kuncoro, M. \& Suhardjono. (2002). Manajemen perbankan: Teori dan aplikasi. Edisi Kedua. Yogyakarta: Badan Penerbitan Fakultas Ekonomi.

Mailakay, M.M., Mangantar, M., \& Baramuli, D. N. (2017). Perbandingan kinerja keuangan PT. Telekomunikasi Indonesia, Tbk. dan PT. XL Axiata, Tbk. Periode 2011-2014 dengan menggunakan konsep rasio keuangan. Jurnal EMBA: Jurnal Riset Ekonomi, Manajemen, Bisnis dan Akuntansi, 5(2), 909-918. https://ejournal.unsrat.ac.id/index.php/emba/article/view/16008

Mende, S., Rate, P. V., \& Tulung, J. (2017). Pengaruh likuiditas, solvabilitas, dan rentabilitas terhadap return saham perusahaan sektor properti dan real estate yang tercatat di Bursa Efek Indonesia periode 2012-2015.Jurnal EMBA: Jurnal Riset Ekonomi, Manajemen, Bisnis Dan Akuntansi, 5(2), 2193-2202. https://ejournal.unsrat.ac.id/index.php/emba/article/view/16517

Munawir, (2010). Analisis laporan keuangan. Edisi Keempat. Yogyakarta: Liberty.

Prabowo, B. (2018). Analisis rasio rentabilitas untuk menilai kinerja keuangan pada PT. Gudang Garam, Tbk.Jurnal SEKURITAS: Saham Ekonomi Keuangan dan Investasi, 1(3), 2581-2696. http://openjournal.unpam.ac.id/index.php/SKT/article/view/1094

Prihadi, T. (2014). Deteksi cepat kondisi keuangan: 7 analisis ratio keuangan. Cetakan Pertama, Jakarta: Pendidikan dan Pembinaan Manajemen.

Pura, R. (2013). Pengantar akuntansi 1: Pendekatan siklus akuntansi. Jakarta: Erlangga.

Rahardjo, B. (2009). Dasar-dasar analisis fundamental saham: Laporan keuangan perusahaan: Membaca, memahami dan menganalisis. Yogyakarta: Gadjah Mada Univesity Press.

Rundupadang, J.A., Mangantar, M., \& Rate, P. V. (2018). Pengaruh rasio keuangan terhadap kinerja bank pemerintah (Persero) yang terdaftar di Bursa Efek Indonesia periode 2008-2016.Jurnal EMBA: Jurnal Riset Ekonomi, Manajemen, Bisnis Dan Akuntansi, 6(3), 1218-1227.https://ejournal.unsrat.ac.id/index.php/emba/article/view/20178

Setiawan, E. (2019). Analisis rasio likuiditas dan rasio rentabilitas untuk menilai kinerja keuangan pada PT. Bank Sumut Kantor Cabang Iskandar Muda. skripsi.http://repository.umsu.ac.id/bitstream/123456789/2531/1/ANALISIS\%20RAS IO\%20LIKUIDITAS\%20DAN\%20RASIO\%20RENTABILITAS\%20UNTUK.pdf

Sucipto, T. (2014). Pengantar akuntansi dan keuangan bidang keahlian bisnis dan manajemen. Bogor: Yudhistira.

Sugiyono. (2010). Metode penelitian kuantitatif, kualitatif dan R\&D. Bandung: Alfabeta.

Sugiyono. (2017). Metode penelitian kombinasi. Bandung: Alfabeta. 